\title{
Outbreak of Orthotomicus erosus (Coleoptera, Curculionidae) on Aleppo Pine in the Mediterranean Region in Croatia
}

\author{
Milan Pernek ${ }^{1}$, Nikola Lacković ${ }^{1 *}$, Ivan Lukić ${ }^{1}$, Nikola Zorić ${ }^{1}$, Dinka Matošević ${ }^{1}$
}

(1) Croatian Forest Research Institute, Division for Forest Protection and Game Management, Cvjetno naselje 41, HR-10450 Jastrebarsko

*Correspondence: e-mail: nikolal@sumins.hr

\begin{abstract}
Citation: PERNEK M, LACKOVIĆ N, LUKIĆ I, ZORIĆ N, MATOŠEVIĆ D 2019 Outbreak of Orthotomicus erosus (Coleoptera, Curculionidae) on Aleppo Pine in the Mediterranean Region in Croatia. Southeast Eur for 10 (1): 19-27. DOI: https://doi. org/10.15177/seefor.19-05

Received: 4 Mar 2019; Revised: 19 Mar 2019; Accepted: 1 Apr 2019; Published online: 19 Apr 2019
\end{abstract}

\begin{abstract}
Background and Purpose: Orthotomicus erosus, Mediterranean pine engraver, is widely distributed across the Mediterranean and southern Europe, Asia and North Africa. It is considered as secondary pest found on recently dead or felled trees, but can also attack weakened living trees. In high population levels this species can attack healthy trees and cause their dieback. Severe outbreaks occur after dry periods, or after fire in adjoining stands in warmer parts of the Mediterranean region, while this scenario has never happened in Croatia up to now. Bark beetles are important forest pests which have already been researched and discussed in relation to climate change, indicating that the predicted increase in temperature would lead to higher survival rates and faster development, thus directly influencing their population dynamics. Increase in temperature may stimulate changes in insects' rate of development, voltinism, population density, size, genetic composition, extent of host plant exploitation, longitudinal and latitudinal distribution. Since climate conditions might have changed in the last few years as predicted in the Mediterranean region, the aim of our research is to document the first outbreak with high population levels of $O$. erosus in Croatia.

Materials and Methods: The extent of dieback was evaluated by counting trees with dieback symptoms on diagonal transects plotted through each of 33 forest management sections of Marjan Forest Park (Split). Trunk sections from several trees with early stage symptoms were collected for further laboratory analysis, which consisted of incubation phase and subsequent morphological identification. During regular yearly surveys in forests of Croatia, the pest was observed on several sites and damages were recorded for both years 2017 and 2018. The records were entered into a map using QGIS version 3.2.1-Bonn. Spatial data was downloaded from DIVA-GIS server. Monitoring efforts were initiated in affected areas where 13 flight barrier pheromone traps (Theyson ${ }^{\circledR}$ ) equipped with pheromone lure Erosowit ${ }^{\circledR}$ (Witasek, Austria) were set-up in late March in state-owned and privately owned forests across Dalmatia. Catches in the traps were collected and $O$. erosus adults were counted on a weekly basis in order to identify the abundance of the pest in monitored sites, as well as to obtain the first information about population dynamics and to assess voltinism.

Results: On-site survey and the evaluation of dieback extent included sampling of $5 \%$ of all trees in Marjan Forest Park ,and the results showed that $23 \%$ of all trees in the forest park were affected by dieback symptoms. Visual examination of trunks, branches and bark showed symptoms of bark beetle infestation, while preliminary on-site examination of the observed adults pointed out to $O$. erosus. After two weeks in controlled conditions, bark beetle adults started to emerge from trunk sections which were placed in several mesh cages for incubation. Morphological identification by using stereomicroscope and the key for European bark beetles resulted in identification of $O$. erosus species. Over the course of the year 2017 one more site was reported to be infested with $O$. erosus, and eight additional sites were reported over the course of year 2018. In total, 446 ha were reported as infested, varying in intensity, in several different management units of state-owned and privately owned forests. The total number of trapped beetles in pheromone traps varied largely among sites. Our data indicate that several generations (at least 5 generations per year) were present in the year 2018.

Conclusions: Sudden surge in observed damages, as well as the number of beetles trapped during monitoring, in years 2017 and 2018 throughout Aleppo pine forests in Dalmatia are the first record of $O$. erosus outbreak in Croatia. $O$. erosus is native to Croatia and so far it has been considered only as a minor pest whose outbreaks have never been recorded.
\end{abstract}


Drought intensity and frequency and aridification trends in the research area (Dalmatia, Croatia) cause cumulative stress to trees and have increased $O$. erosus occurrence. $O$. erosus is expected to exhibit increased voltinism, better overwintering performance and earlier spring flights. Our first results confirm this epidemic stage of $O$. erosus with high abundances in Dalmatia in 2018 and at least 5 generations per year, which alter the population level of this pest. Finally, with high dispersal abilities of $O$. erosus through active flight and easy transportation with infested material (logs and branches with bark), $O$. erosus has the potential to become an important forest pest in Croatia. Thus, extensive studies on its biology, ecology, natural enemies and interaction with ophiostomatoid fungal species are needed in order to predict further spread and suggest viable and effective management measures.

Keywords: Mediterranean pine engraver, climate change, Pinus halepensis, Pityogenes calcaratus, Tomicus destruens

\section{INTRODUCTION}

Bark beetles (Coleoptera; Curculionidae; Scolytinae) have been documented as a relevant ecological and economic factor in ecosystem functioning and their activity can indicate the health condition and vitality of forests [1]. They are also very important forest pests that can cause serious dieback of forests on huge areas [2-4] and enormous wood volume loss [5]. Out of many species only a few are able of causing tree dieback, and usually they have fluctuations from low abundance for lengthy periods when they are limited to stressed trees [6]. However, their populations can rise suddenly and spread over large areas, sometimes killing huge numbers of healthy trees as well.

There are 42 bark beetle species recorded living on Mediterranean conifers and usually they have been registered on weakened trees only [1, 7]. According to Pfeffer [8] and Knižek [9], 11 bark beetle species have been listed for Croatia, developing on Aleppo pine trees (Pinus halepensis Mill.), out of which only 3 species have the potential to behave like a pest (Tomicus destruens Woll., Orthotomicus erosus Woll. and Pityogenes calcaratus Eich.).

Orthotomicus erosus, Mediterranean pine engraver, is widely distributed across the Mediterranean and southern Europe, Asia and North Africa. It has been introduced to Fiji, South Africa, Swaziland [10] and the USA [11]. It can occur in association with other bark beetle species (Pityogenes calcaratus, Tomicus destruens [12]) and in symbiotic relationship with blue stain fungi (Ophiostomatidae) [13]. It is considered as a secondary pest found on recently dead or felled trees, but can also attack weakened living trees (e.g. under drought stress). In high population levels this species can attack healthy trees and cause their dieback [14]. Severe outbreaks occur after dry periods, or after fire in adjoining stands in warmer parts of the Mediterranean region $[15,16]$.

Mediterranean forests are one of the world's biodiversity hotspots characterized by a variety of environmental conditions with an array of plant and animal species diversity. As such, they represent a major socio-economic component for tourists that visit the Mediterranean every year, with their unique biological richness and multiple values [17]. However, today they are under severe threat from climate change and it is predicted that Mediterranean forest ecosystems will suffer from its impacts by 2050 [17]. Mediterranean forests composed mostly of drought-tolerant Mediterranean oak species [18] have been over-used for their multiple resources. Huge amount (75\%) of these ecosystems has been destroyed by humans already in the $19^{\text {th }}$ century [19]. Aleppo pine has been widely planted in reforestation of the degraded areas as a fast-growing pioneer species. First reforestation efforts in Croatia were documented in $18^{\text {th }}$ century [20]. Aleppo pine was chosen as the most suitable species because of its drought tolerance [18] and it was widely distributed on the coast of Croatia [21]. Today, Aleppo pine plays an important role in edaphic preparation for other native species (e.g. Quercus ilex L.) [22]. This pine species is also very important in preservation of multiple environmental services provided by Mediterranean forests (e.g. carbon sequestration, biodiversity, landscape quality, soil and water protection, landscape and recreational role). However, this widely growing species is endangered by prolonged drought periods that cause water deficit and weaken the trees, as well as by forest fires, pests and diseases [23-25]. New examples of climate change induced pest occurrences give rise to special concerns since these changes could have long-term effects on the vitality and health status of Aleppo pine forests in the coastal region of Croatia $[25,26]$. Bark beetles have already been researched and discussed in relation to climate change, indicating that predicted increase in temperature would lead to higher survival rates and faster development, thus directly influencing their population dynamics [27].

Climate change could indirectly negatively influence forest ecosystems through range expansion and changing of seasonal phenology of insect pests, resulting in faster development and higher feeding rates of phytophagous insects [27]. This negative influence is likely to be accelerated with increased temperatures and frequency and intensity of droughts with extended growth period of vegetation predicted for Mediterranean forests [28]. Other negative influences of climate change on forests might be seen in physiological changes in tree defense mechanisms and indirect effects through changes in abundances of natural enemies and competitors [29]. Temperature may stimulate changes in insects' rate of development, voltinism, population density, size, genetic composition, extent of host plant exploitation, longitudinal and latitudinal distribution [14, 30].

Among bark beetles, $O$. erosus is considered as a secondary pest which infests already fallen and/or stressed trees [31]. Attacks of $O$. erosus and $P$. calcaratus have already been recorded in warmer Mediterranean regions such as Israel [32], Iran [33], Morocco [34], Turkey [35] and Tunis [36]. According to written records, this species has not yet been observed in Croatia $[25,37]$. When it comes to bark beetles in the Mediteranean part of Croatia, only very local outbreaks of $T$. piniperda L. or $T$. destruens have been recorded [24, 38, 39]. However, it was predicted that climate change increases 
the possibility that the outbreaks will spread and increase in frequency, and that Mediterranean forests could become more vulnerable to their attacks than temperate and boreal regions [1]. In outbreaks of pests correlated to climatic change outside their historical ranges, northwards spreading or elevation expanding have already been well documented [e.g. 36, 41-42].

According to Lieutier et al. [1], O. erosus infesting Aleppo pine may develop up to 4 generations per year or even up to 7 generations [15, 40], while in Croatia only 2 to 3 generations have been described [43]. Males of 0 . erosus bore through the bark into the cambium where they mate with several females. Females construct egg galleries and can oviposit up to 75 eggs in the niches along the galleries [12]. Larvae pass through three instars and gnaw their galleries perpendicularly to maternal ones. The adults perform maturation feeding beneath the still moist bark and if the bark is too dry, they move to another tree [12]. Insect overwinters as an adult and beetles fly in spring at temperatures of $12-14{ }^{\circ} \mathrm{C}[15,41]$. The beetles choose rough-barked tree trunk and branches larger than $5 \mathrm{~cm}$ in diameter for breeding. Smooth barked sections of the trunk are used for maturation feeding, while lower trunk parts of old trees with too thick bark are not suitable for attack [12].

Considering that climate conditions for multiple generations of $O$. erosus described by Mendel $[15,40]$ were not fulfilled could be the reason why outbreaks of this insect have never been documented in Croatia [24]. Though, these conditions might have changed in the last few years as predicted [28].

The aim of our research is to document the first outbreak with high population levels of $O$. erosus in Croatia.

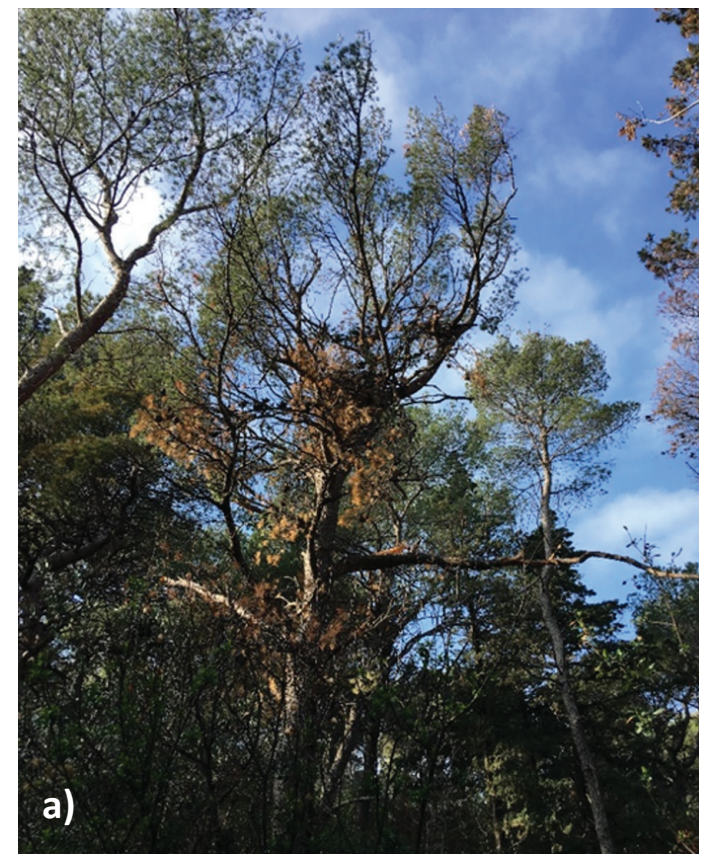

\section{MATERIALS AND METHODS}

First Record of Symptoms and Identification of the Pest

In 2017, unusual wilting and drying of Aleppo pine

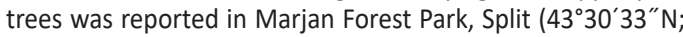
$\left.16^{\circ} 24^{\prime} 38^{\prime \prime} \mathrm{E}\right)$. The report triggered intensive on-site survey in order to determine the extent and cause(s) of dieback of Aleppo pine trees. The extent of dieback was evaluated by counting trees with dieback symptoms on the diagonal transects plotted through each of 33 forest management sections of the forest park. The identification of dieback causative agent was performed by visual examination of trunks and branches (Figure 1). Trunk sections from several trees with early stage symptoms were collected for further laboratory analysis. Samples were taken to entomological laboratory of Croatian Forest Research Institute, Jastrebarsko, Croatia.

Laboratory analysis consisted of incubation phase and subsequent morphological identification. Incubation was performed by distributing trunk sections (collected during field survey) into mesh cages and subjecting them to controlled temperature of $20( \pm 2)^{\circ} \mathrm{C}$ and $\mathrm{L}: \mathrm{D}=16: 8$. Trunk sections were sprayed with distilled water across the entire surface once per day in order to maintain bark moisture. Upon emergence, adult beetles were collected from mesh cages and morphologically identified. Identification was performed by visual examination, using stereoscopic light microscope Olympus SZX7 and the key for bark beetle identification $[8,9]$.

\section{Localities and Years of Record}

Similar symptoms were observed also in other Aleppo pine forests in Dalmatia, and on-site training was organized

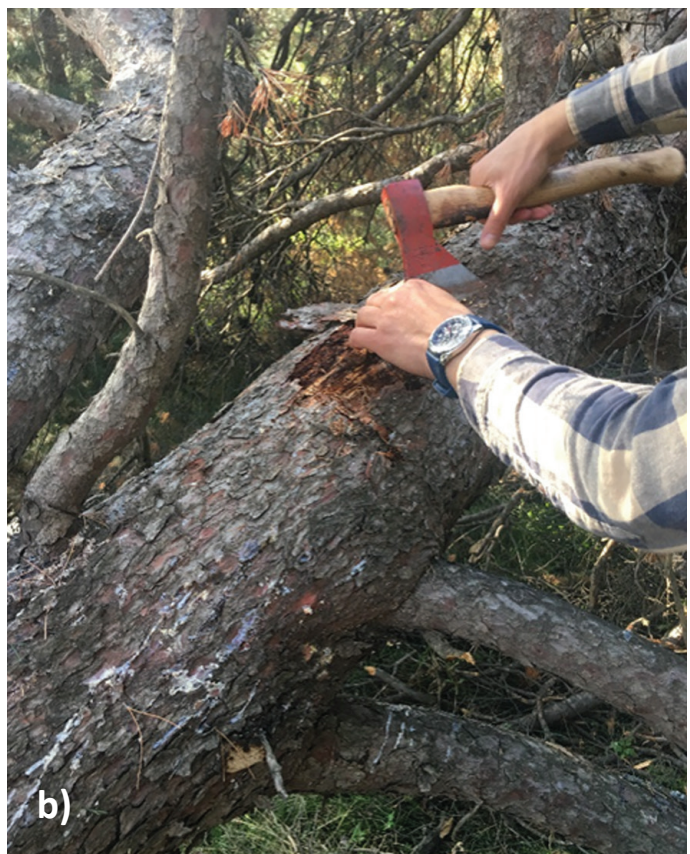

FIGURE 1. a) Green crown of freshly infested Aleppo pine tree; b) Examination of the trunk and branches for infestation symptoms. 
in the summer of 2017 in Biograd Forestry Office in order to familiarize regional foresters with new threats posed by the potential outbreak of $O$. erosus and to teach them how to identify damages caused by this bark beetle. During regular yearly surveys in forests of Croatia, the pest was observed on several sites and damages were recorded for both years 2017 and 2018. The records were entered into a map using QGIS version 3.2.1-Bonn. Spatial data was downloaded from DIVAGIS server.

\section{Monitoring of 0 . erosus in Dalmatia}

After surprising record of damage done by 0 . erosus in 2017, monitoring efforts have been initiated. Thirteen flight barrier pheromone traps (Theyson ${ }^{\circledR}$ ) equipped with pheromone lure Erosowit ${ }^{\circledR}$ (Witasek, Austria) were set up in late March in state-owned and privately owned forests across Dalmatia. Catches in the traps were collected and 0 . erosus adults were counted on a weekly basis in order to identify the abundance of the pest in monitored sites, as well as to obtain the first information about population dynamics and to assess voltinism.

\section{RESULTS}

First Report of Symptoms and Identification of the Pest

On-site survey and evaluation of dieback extent included sampling of $5 \%$ of all trees in Marjan Forest Park, and the results showed that $23 \%$ of all trees in the forest park were affected by dieback symptoms by the end of 2018. Visual examination of trunks, branches and bark showed symptoms of bark beetle infestation, while preliminary on-site examination of the observed adults pointed out to 0 . erosus (Figure 2).

After two weeks in controlled conditions, bark beetle adults started to emerge from trunk sections which were placed in 10 mesh cages for incubation. Morphological identification by using stereomicroscope and the key for European bark beetles resulted in positive identification of the species as 0 . erosus.

\section{Localities and Years of Record}

Over the course of the year 2017, aside from Marjan, one more site was reported to be infested with 0 . erosus, and eight additional sites were reported over the course of the year 2018 (Figure 3). In total, 446 ha and about $9.000 \mathrm{~m}^{3}$ of wood mass were reported as infested, varying in intensity, in several different management units of state-owned and privately owned forests in Šibenik-Knin County in 2018 (Table 1).

\section{Monitoring of $\boldsymbol{O}$. erosus in Dalmatia}

Pheromone traps for monitoring the abundance of $O$. erosus in Aleppo pine forests in Dalmatia were set up on 13 sites in total (both in state-owned and privately owned forests). The total number of trapped beetles varied largely among sites (from 21,442 specimens to 140,448 specimens trapped in Šibenik) and fluctuated substantially over the course of the year (Figure 4 and 5). Our data indicate that several generations (at least 5 generations per year) were present in the year 2018. These data need further validation in the years that follow.
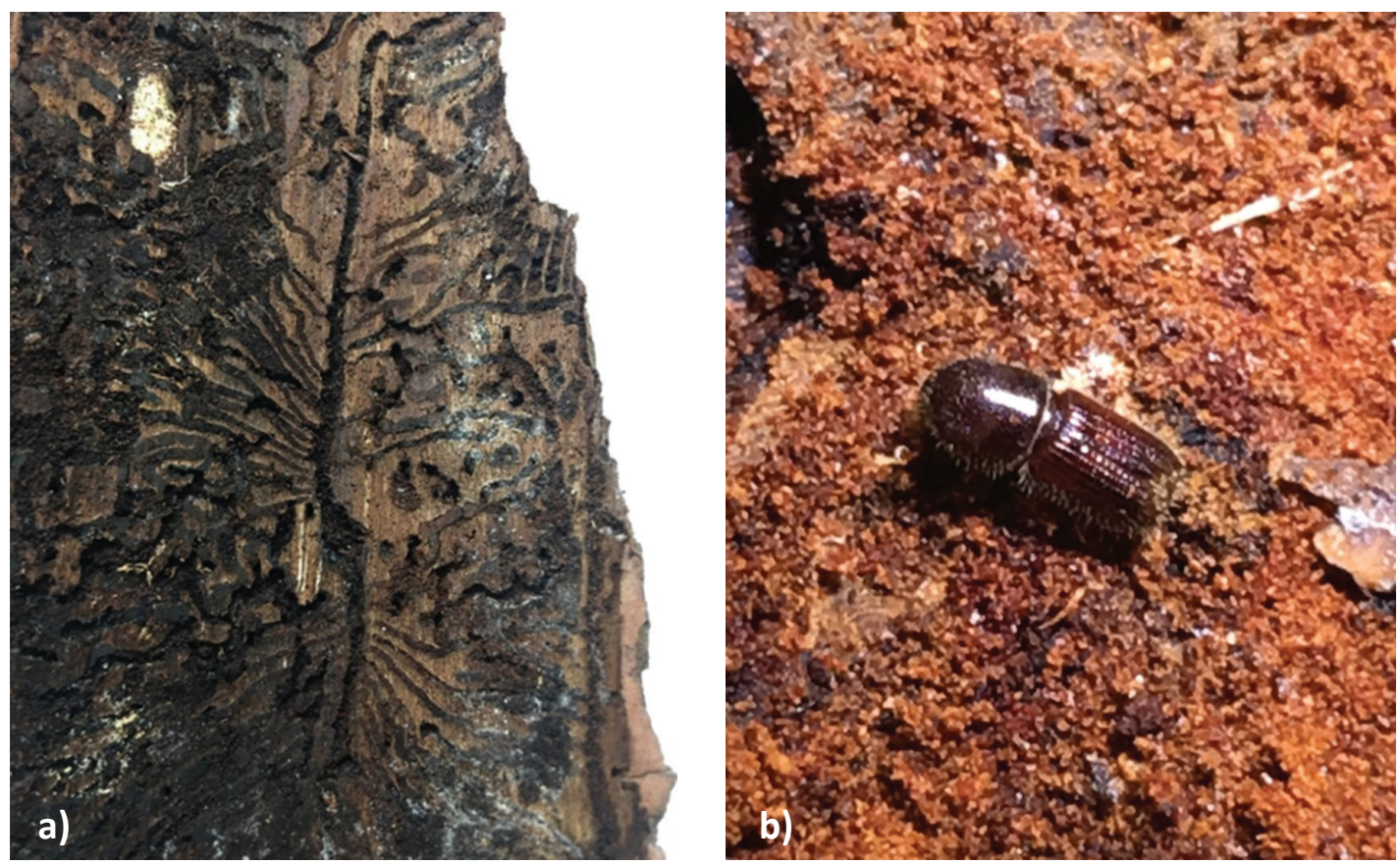

FIGURE 2. O. erosus bark beetle, observed on the bark of Aleppo pines in Marjan Forest Park: a) Bark beetle galleries and b) Adult stage of beetles. 
TABLE 1. Area and wood mass infested by O. erosus reported for private, protected and state-managed forests in 2018.

\begin{tabular}{|c|c|c|c|c|c|c|c|}
\hline \multirow[b]{2}{*}{ Forest Office } & \multirow[b]{2}{*}{ Forestry } & \multirow[b]{2}{*}{ Management unit } & \multicolumn{2}{|c|}{ WGS coordinates } & \multicolumn{3}{|c|}{ Infestation } \\
\hline & & & $\mathbf{N}$ & E & $\begin{array}{l}\text { Area } \\
\text { (ha) }\end{array}$ & $\begin{array}{c}\text { Wood mass } \\
\left(\mathrm{m}^{3}\right)\end{array}$ & $\begin{array}{c}\text { Intensity } \\
(\%)\end{array}$ \\
\hline Private forests & Šibenik-Knin County & Šibenske šume & 43.7448 & 15.9695 & 10.5 & $n / a$ & $1-20$ \\
\hline \multirow{4}{*}{$\begin{array}{l}\text { State-protected } \\
\text { forests }\end{array}$} & Split & Marjan & 43.5139 & 16.4092 & 196.0 & 5,900 & $21-40$ \\
\hline & Korčula & Ošjak & 42.9606 & 16.6794 & 18.0 & 1,800 & $21-40$ \\
\hline & Makarska & Osejava & 43.2886 & 17.0138 & 70.0 & 150 & $1-20$ \\
\hline & Dubrovnik & Lokrum & 42.6276 & 18.1112 & 70.0 & 100 & $1-20$ \\
\hline \multirow{6}{*}{$\begin{array}{l}\text { State-managed } \\
\text { forests } \\
\text { Split }\end{array}$} & \multirow{3}{*}{ Biograd } & Biograd & 43.9308 & 15.4802 & 25.0 & 400 & $21-40$ \\
\hline & & Pašman-Vrgada & 43.9540 & 15.3494 & 31.0 & 250 & $41-60$ \\
\hline & & Turanj & 43.9978 & 15.4266 & 3.0 & 25 & $1-20$ \\
\hline & Korčula & Šaknja Rat & 42.9438 & 16.7932 & 17.5 & 200 & $1-20$ \\
\hline & \multirow{2}{*}{ Zadar } & Nin-Kožino & 44.1996 & 15.2144 & 2.0 & 10 & $1-20$ \\
\hline & & Starigrad & 44.3499 & 15.3502 & 3.0 & 20 & $1-20$ \\
\hline & Totals & & & & 446.0 & 8855.0 & $1-60$ \\
\hline
\end{tabular}

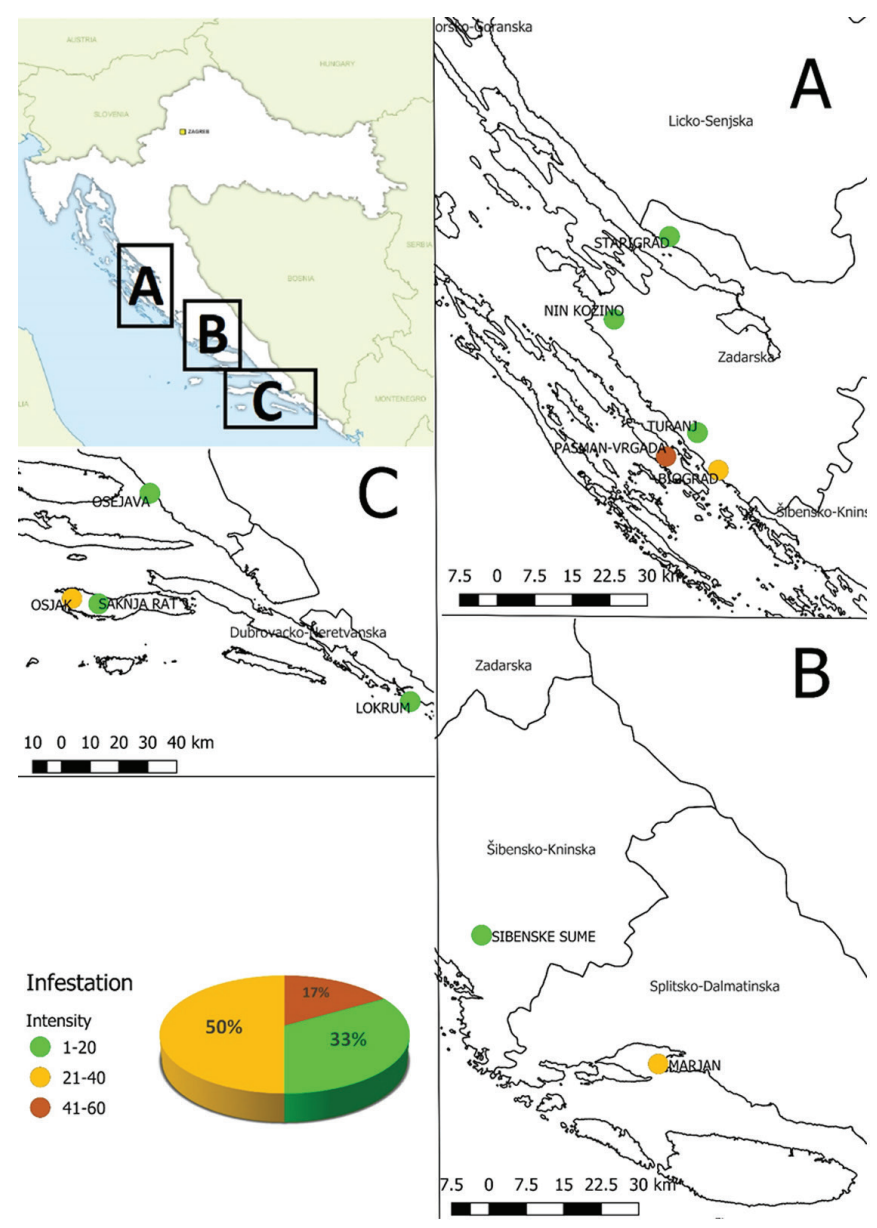

FIGURE 3. Map of management units reported as infested by O. erosus in 2018. Coloration according to the reported infestation intensity. The pie chart represents area ratios of the reported infestation intensities. 


\section{Privately owned forests}

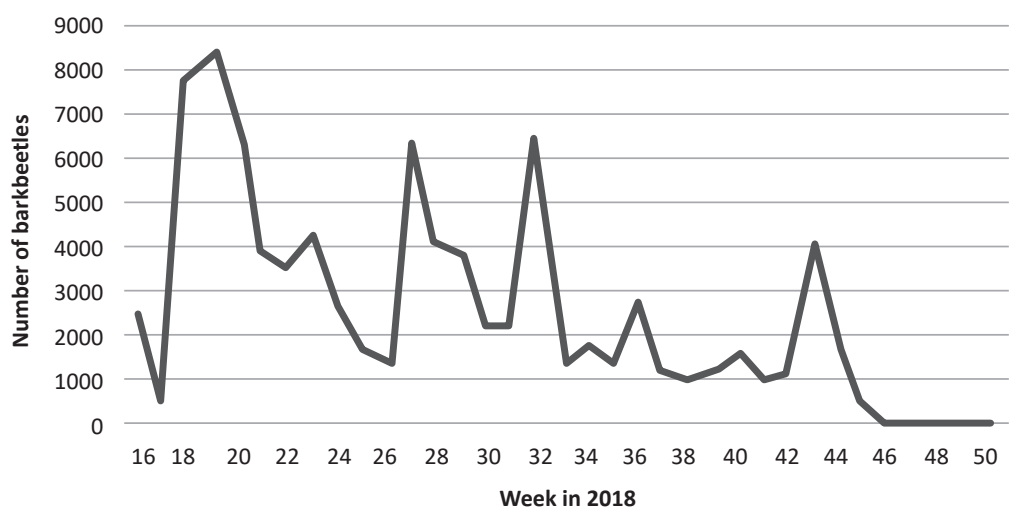

FIGURE 4. Weekly distribution of the total number of trapped O. erosus beetles per trap in 2018 in privately owned forests.

\section{State-owned forests}

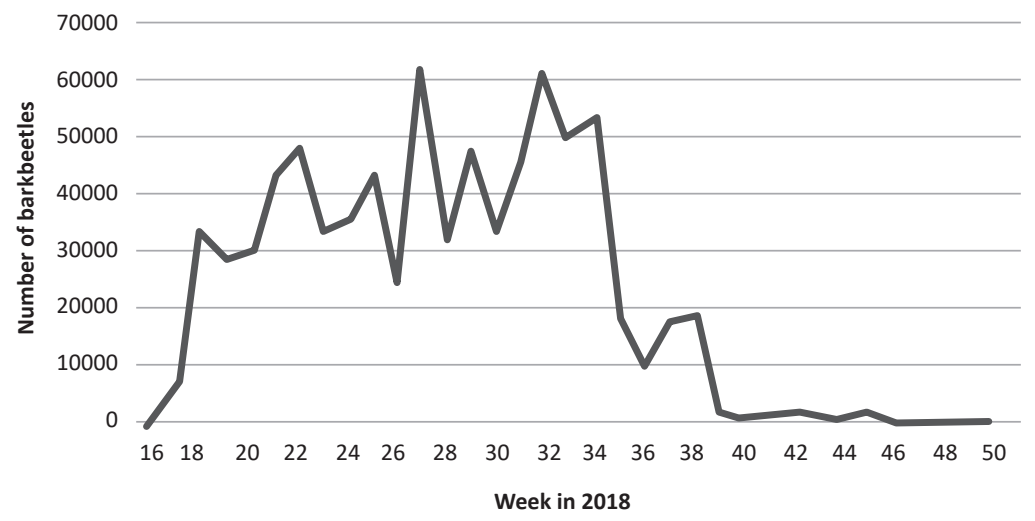

FIGURE 5. Weekly distribution of the average number of trapped O. erosus beetles per trap in 2018 in state-owned forests.

\section{DISCUSSION}

Sudden surge in the observed damages, as well as the number of beetles trapped during monitoring, in years 2017 and 2018 throughout Aleppo pine forests in Dalmatia, as presented in this paper, is the first record of $O$. erosus outbreak in Croatia. O. erosus is native to Croatia and so far it has been considered only as a minor pest and its outbreaks have never been recorded [23, 24, 39, 43, 44]. Thus, the outbreak came as a surprise, rising questions about causes of this phenomenon, predictions of further expansions, as well as the availability and efficacy of control measures. Drought intensity and frequency have increased in the region of $O$. erosus occurrence (Dalmatia, Croatia) and aridification trends cause cumulative stress to trees [43]. More evidence shows that population dynamics of forest insects have already been affected by climate change [14, 26, 44, 46, 47]. Temperature is the primary climatic factor affecting insects since they are poikilothermic organisms and respond quickly to temperature changes [29]. The responses manifest through changes in population density and distribution range of the affected species [48]. Generally, in mid-latitude regions temperature increases associated with climatic changes could result in changes of beetle ecology, such as extension of geographical range, increased overwintering, increased number of generations, extension of development season and so on [49]. It seems to be very important that the beetles jointly overcome tree defense mechanisms, and temperature positively influences such synchronization [50]. Furthermore, reduced production of active defenses could reduce tree resistance to bark beetle attacks [51].

According to IPCC [28], intensity, duration and frequency of drought have increased in semi-arid areas, e.g. in the Mediterranean region, which manifests as aridification process capable to trigger forest diebacks [52]. Trees stressed by aridification processes are becoming more prone to insect infestations, which leads to an increase of injury and eventually to tree death $[53,54]$. On the other 
hand, longitudinal and altitudinal range shifts caused by climate change have already been documented for various species of forest insects (as reviewed in [14]). Furthermore, temperature increase has been predicted to influence the distribution of Mediterranean species of bark beetles (e.g. T. destruens), enabling them to spread northwards and feed on new hosts in new areas [54].

O. erosus can establish up to 7 generations per year [40] and it exhibits accelerated development at high temperatures with no thermic limitations for mass production, which enables it to pass from endemic to epidemic stage within months $[12,15,40]$. With predictions for temperature change in the Mediterranean region towards warmer winters and warmer and drier summers [14, 28], 0. erosus is expected to exhibit increased voltinism, better overwintering performance and earlier spring flights. This might probably ultimately increase its population size, resulting in more severe and widespread damages as reported for other bark beetle species [56, 57]. Our first results confirm this epidemic stage of $O$. erosus with high abundances in Dalmatia in 2018 and at least 5 generations per year, which alter the population significance of this pest.

It is very hard to discriminate direct from indirect events of climate change [30], which is why the overall impact of all interacting factors should be considered. With this in mind, natural enemies are also influenced by climate change as the host and parasitoid synchronization may be disrupted under altered climate conditions [27]. Unexpected events, e.g. storms which are more frequent and are predicted to increase (as reviewed in [14]), can provide an abundant source of fresh food for bark beetles, increasing the buildup of populations. High availability of food source (stressed trees, freshly felled trees) together with increased voltinism can lead to permanently high bark beetle populations that are able to attack healthy trees, enabling them to become primary pests [58].

Furthermore, 0 . erosus is associated with several ophiostomatoid species [13, 59]. Some ophiostomatoid fungal species in association with bark beetles show increased virulence and it is assumed that they help their vectors, bark beetles, to break the defensive mechanisms of the host plant. This is a successful strategy for weakening the host plant and plays an important role in the attack strategy of bark beetles $[60,61]$. How and to what extent could the temperature increase affect fungal species remains unknown, making this issue one of the questions that should be addressed in future studies. Our first preliminary research has shown several species of ophiostomatoid fungal species (Pernek and Matek, unpublished data) isolated from samples taken from the same localities shown in Table 1.

Finally, with high dispersal abilities of $O$. erosus through active flight and easy transportation with infested material (logs and branches with bark), 0 . erosus has the potential to become a serious forest pest in Croatia. Thus, extensive studies on its biology, ecology, natural enemies and interaction with ophiostomatoid fungi are needed in order to predict its further spread and to suggest viable and effective management measures.

\section{Acknowledgements}

We would like to thank to Marjan Forest Park Public Institution and its employees for support and cooperation. We would also like to thank to the Ministry of Agriculture of the Republic of Croatia for support through Diagnosis and Prognosis Service (IPP), as well as Croatian Forests Ltd. for cooperation in field observations, monitoring and reporting.

\section{REFERENCES}

1. LIEUTIER F, MENDEL Z, FACCOLI M 2016 Bark Beetles of Mediterranean Conifers. In: Paine DT, Lieutier F (eds) Insects and Diseases of Mediterranean Forest Systems. Springer, Basel, Switzerland, pp 105-197

2. DALE VH, JOYCE LA, MCNULTY S, NIELSON RP, AYRES MP, FLANNIGEN MD, HANSON PJ, IRLAND LC, et al. 2001 Climate change and forest disturbances: Climate change can affect forests by altering the frequency, intensity, duration, and timing of fire, drought, introduced species, insect and pathogen outbreaks, hurricanes, windstorms, ice storms, or landslides. BioScience 51 (9): 723-734. DOI: https://doi.org/10.1641/0006-3568(2001)051[0723:CCAF D]2.0.CO;2

3. BENTZ B, LOGAN J, MCMAHON J, ALLEN CD, AYRES MP, BERG E, CARROLL A, HANSEN M, et al. 2009 Bark beetle outbreaks in western North America: causes and consequences. University of Utah, Salt Lake City, Utah, United States, 42 p. URL: https://www.fs.fed.us/rm/pubs other/rmrs 2009 bentz b001.pdf (31 March 2019)

4. SEIDL R, SCHELHAAS MJ, LEXER MJ 2011 Unraveling the drivers of intensifying forest disturbance regimes in Europe. Glob Change Biol 17 (9): 2842-2852. DOI: https:// doi.org/10.1111/i.1365-2486.2011.02452.x
5. SCHELHAAS MJ, NABUURS GJ, SCHUCK A 2003 Natural disturbances in the European forests in the 19th and 20th centuries. Glob Change Biol 9 (11): 1620-1633. DOI: https://doi.org/10.1046/i.1365-2486.2003.00684.x

6. SAFRANYIK L, CAROLL AL 2006 The biology and epidemiology of the mountain pine beetle in lodgepole pine forests. In: Safranyik L, Wilson WR (eds) The mountain pine beetle: a synthesis of biology, management and impact on lodgepole pine. Natural Resources Canada, Canadian Forest Service, Pacific Forestry Centre, Victoria, British Columbia, Canada, pp 3-66

7. KNIŽEK M, BEAVER R 2004 Taxonomy and systematics of bark and ambrosia beetles. In: Lieutier F, Day KR, Battisti A, Gregoire JC, Evans HF (eds) Bark and wood boring insects in living trees in Europe, a synthesis. Springer, Dordrecht, The Netherlands, pp 41-54

8. PFEFFER A 1995 Zentral- und westpaläarktische Borkenund Kernkäfer. Pro Entomologia, Naturhistorisches Museum,Basel, Switzerland, $310 p$

9. KNIŽEK M 2011 Scolytinae. In: Löbl I, Smetana A (eds) Catalogue of palearctic coleoptera, volume 7. Apollo Books, Vester Skerninge, Denmark, pp 204-251 
10. WOOD SL, BRIGHT DE 1992 A catalog of Scolytidae and Platypodidae (Coleoptera), Part 2: Taxonomic index. Volume A \& B. Great Basin naturalist memoirs 13: 1-1557

11. HAACK RA 2004 Orthotomicus erosus: A new pine-infesting bark beetle in the United States. Newsletter of the Michigan Entomological Society 49 (3-4): 3. URL: (https:// www.nrs.fs.fed.us/pubs/jrnl/2004/nc 2004 Haack 001. pdf) (31 March 2019)

12. MENDEL Z, HALPERIN J 1982 The biology and behavior of Orthotomicus erosus in Israel. Phytoparasitica 10 (3): 169181. DOI: https://doi.org/10.1007/BF02994526

13. HUMAN ZR, SLIPPERS B, DE BEER ZW, WINGFIELD MJ, VENTER SN 2017 Antifungal actinomycetes associated with the pine bark beetle, Orthotomicus erosus, in South Africa. S Afr J Sci 113 (1-2): 34-40. DOI: http://dx.doi. org/10.17159/sajs.2017/20160215

14. LIEUTIER F, PAINE TD 2016 Responses of Mediterranean Forest Phytophagous Insects to Climate Change. In: Paine DT, Lieutier F (eds) Insects and Diseases of Mediterranean Forest Systems. Springer, Basel, Switzerland, pp 801-858

15. MENDEL Z 1983 Seasonal history of Orthotomicus erosus (Coleoptera: Sclytidae) in Israel. Phytoparasitica 11 (1): 1324. DOI: https://doi.org/10.1007/BF02980707

16. SARIKAYA O, ŞEN I 2017 Population genetic structure of Orthotomicus erosus (Wollaston, 1857) (Coleoptera: Curculionidae, Scolytinae) in pine forests of the Mediterranean Region of Turkey. Appl Ecol Env Res 15 (4): 915-928. DOI: http://dx.doi.org/10.15666/ aeer/1504 915928

17. CECI P, BESACIER C, SAKET M, HAYDER M, BERRAHMOUNI N State of Mediterranean Forests (SoFMF). In: Arid Zone Forests and Forestry Working Papers. Forestry Department, Food and Agriculture Organization of the United Nations, Rome, Italy, 18 p. URL: http://www.fao.org/3/ma723e/ ma723e00.pdf (31 March 2019)

18. TIMBAL J, AUSSENAC G 1996 An overview of ecology and silviculture of indigenous oaks in France. Ann Sci Forest 53 (2-3): 649-661. DOI: https://doi.org/10.1051/ forest:19960243

19. QUEZEL P, MEDAIL F 2003 Écologie et biogéographie des forêts du bassin méditerranéen. Elsevier Masson, Paris, France, $572 \mathrm{p}$

20. MATIĆ S, ORŠANIĆ M, ANIĆ I, DRVODELIĆ D, TOPIĆ V, MIKAC S, ĐURĐEVIĆ Z 2011 Afforestation in the croatian mediterranean region. In: Matić $S$ (ed) Forests of the croatian mediterranean. Academy of forestry sciences, Zagreb, Croatia, pp 393-426

21. TRINAJSTIĆ । 2011 Phytogeographic distribution of vegetation cover. In: Matić S (ed) Forests of the croatian mediterranean. Academy of forestry sciences, Zagreb, Croatia, pp 182-192

22. KRPAN APB, PORŠINSKY T, ZEČIĆ Ž, STANKIĆ I 2011 Utilisation characteristics of aleppo pine (Pinus halepensis Mill.) forest cultures. In: Matić S (ed) Forests of the croatian mediterranean. Academy of forestry sciences, Zagreb, Croatia, pp 670-683

23. GLAVAŠ M, ĐURĐEVIĆ Z, JURJEVIĆ P 2011 Forest fires on karst. In: Matić S (ed) Forests of the croatian mediterranean. Academy of forestry sciences, Zagreb, Croatia, pp 573-584

24. HRAŠOVEC B, HARAPIN M, PERNEK M 2011 Entomological complex of mediterranean forests. In: Matić $\mathrm{S}(e d)$ Forests of the croatian mediterranean. Academy of forestry sciences, Zagreb, Croatia, pp 556-572

25. PERNEK M, NOVAK AGBABA S, LACKOVIĆ N, ĐOĐ N, LUKIĆ I, WIRTH S 2012 The role of biotic factors on pine (Pinus spp.) decline in north Dalmatia (in Croatian with English summary). Sumar list 136 (7-8): 343-354
26. FRANJEVIĆ M, PERNEK M, HRAŠOVEC B 2012 Bark beetle populations in Croatia during the period 2008-2009 monitoring data and research observations. In: Steyrer G, Tomiczek C, Hoch G, Lackner C (eds) Forstschutz Aktuell 55 , Proceedings of the third meeting of forest protection and forest phytosanitary experts, Vienna, Austria, 14-16 October 2009. Research and Training Centre for Forests, Natural Hazards and Landscape, Vienna, Austria, pp 26-27

27. BATTISTI A, LARSSON S 2015 Climate change and insect distribution range. In: Björkman C, Niemelä P (eds) Climate change and insect pests. $\mathrm{CABI}$, Wallingford, Oxfordshire, England, pp 1-15

28. IPCC 2014 Summary for Policymakers. Cambridge University Press, Cambridge, United Kingdom and New York, NY, USA, 32 p. URL: https://www.researchgate.net/ publication/272150376 Climate change 2014 impacts adaptation and vulnerability - IPCC WGII AR5 summary for policymakers

29. AYRES MP, LOMBARDERO MJ 2000 Assessing the consequences of global change for forest disturbance from herbivores and pathogens. Science of the Total Environment 262 (3): 263-286. DOI: https://doi.org/10.1016/S00489697(00)00528-3

30. BALE JS, MASTERS GJ, HODKINSON ID, AWMACK C, BEZEMER TM, BROWN VK, BUTTERFIELD J, BUSE A, et al. 2002 Herbivory in global climate change research: direct effects of rising temperature on insect herbivores. Glob Chang Biol 8 (1): 1-16. DOI: https://doi.org/10.1046/ j.1365-2486.2002.00451.x

31. MORGAN RE, DE GROOT P, SMITH SM 2004 Susceptibility of pine plantations to attack by the pine shoot beetle (Tomicus piniperda) in southern Ontario. Can J Forest Res 34 (12): 2528-2540. DOI: https://doi.org/10.1139/x04-135

32. MENDEL Z, MADAR Z, GOLAN Y 1986 Hymenopterous parasitoids of pine bark beetles in Israel. Hasadeh 66: 1899-1901

33. MENDEL Z 1988 The relation of bast scale and bark beetle outbreaks to management of pine plantations in Israel. In: Payne TL, Saarenmaa H (eds) XVII International Congress of Entomology, Proceedings of the IUFRO working party, Vancouver, British Columbia, Canada. pp 329-335

34. LIEUTIER F, GHAIOULE D, YART A, SAUVARD D 2002 Attack behavior of pine bark beetles in Morocco and association with phytopathogenic fungi. Ann Rech For Maroc 35: 96109

35. SARIKAYA O, AVCI M 2010 Distribution and biology of the Mediterranean pine shoot beetle Tomicus destruens (Wollaston, 1985) in the western Mediterranean region of Turkey. Turkiye Entomolji Dergisi 34 (3): 289-298

36. BEN JAMAA ML, LIEUTIER F, YART A, JERRAYA A, KHOUJA ML 2007 The virulence of phytopathogenic fungi associated with the bark beetles Tomicus piniperda and Orthotomicus erosus in Tunisia. Forest Pathol 37 (1): 51-63. DOI: https:// doi.org/10.1111/j.1439-0329.2007.00478.x

37. CAROLL AL, TAYLOR SW, RÉGNIÈRE J, SAFRANYIK L 2004 Effects on climate change on range expansion by the mountain pine beetle in British Columbia. In: Shore TL, Brooks JE, Stone JE (eds) Mountain Pine Beetle Symposium: Challenges and Solutions, Information Report BC-X-399, Kelowna, British Columbia, Canada, 30-31 October 2003. Canadian Forest Service, Pacific Forestry Centre, Victoria, British Columbia, Canada, pp 223-232

38. PERNEK M, HRAŠOVEC B, ŽUPANIĆ M 2003 Beetle fauna captured in traps baited with Tomicus piniperda pheromone blends in a pine stand in central Croatia. In: McManus ML, Liebhold AM (eds) Proceedings: Ecology, Survey and Management of Forest Insects Gen. Tech. Rep. NE-311, Krakow, Poland, 1-5 September 2002. U.S. Dept. of Agriculture, Forest Service, Northeastern Research Station, Newtown Square, PA, USA, pp 87-89

https://www.seefor.eu 
39. NOVAK P 1952 Kornjaši Jadranskog primorja: (Coleoptera). Jugoslavenska Akademija znanosti i umjetnosti, Zagreb, Jugoslavija, $521 \mathrm{p}$

40. MENDEL Z, MADAR Z, GOLAN Y 1985 Comparison of the seasonal occurrence and behavior of seven pine bark beetles (Coleoptera. Scolytidae) in Israel. Phytoparasitica 13 (1): 21-32. DOI: https://doi.org/10.1007/BF02994434

41. SAMBARAJU KR, CAROLL AL, ZHU J, STAHL K, MOORE RD, AUKEMA BH 2012 Climate change could alter the distribution of mountain pine beetle outbreaks in western Canada. Ecography 35 (3): 211-223. DOI: https://doi. org/10.1111/i.1600-0587.2011.06847.x

42. WEED AS, AYRES MP, HICKE JA 2013 Consequences of climate change for biotic disturbance in North American forests. Ecol Monogr 83 (4): 441-470. DOI: https://doi. org/10.1890/13-0160.1

43. SPAIĆ I 1964 Experimental control of bark beetles on aleppo pine by the sap-flow method (in Croatian with German summary). Sumar list 5-6: 226-236

44. CHARARAS C, M'SADDA K 1973 Study of the biology, behaviour and the action of cobalt60 ionising radiations in Orthotomicus erosus Woll., (Coleoptera Scolytidae), a specific pest of conifers. Archives de I'Institut Pasteur de Tunis 50 (3): 243-265

45. CAMARERO JJ, GAZOL A, SANGÜESA-BARREDA G, OLIVIA J, VINCENTE-SARRANO SM 2015 To die or not to die: early warnings of tree dieback in response to a severe drought. J Ecol 103 (1): 44-57. DOI: https://doi.org/10.1111/13652745.12295

46. NETHERER S, SCHOPF A 2010 Potential effects of climate change on insect herbivores in European forests - General aspects and the pine processionary moth as specific example. Forest Ecol Manag 259 (4): 831-838. DOI: https://doi.org/10.1016/i.foreco.2009.07.034

47. SANGÜESA-BARREDA G, LINARES JC, CAMARERO J 2015 Reduced growth sensitivity to climate in bark-beetle infested Aleppo pines: Connecting climatic and biotic drivers of forest dieback. Forest Ecol Manag 357 (1): 126137. DOI: https://doi.org/10.1016/i.foreco.2015.08.017

48. PURESWARAN DS, ROQUES A, BATTISTI A 2018 Forest insects and climate change. Curr Forestry Rep 4 (2): 35-50. DOI: https://doi.org/10.1007/s40725-018-0075-6

49. HILL JK, GRIFFITHS HM, THOMAS CD 2011 Climate change and evolutionary adaptations at species' range margins. Annu Rev Entomol 56: 143-159. DOI: https://doi. org/10.1146/annurev-ento-120709-144746

50. PORTER JH, PARRY ML, CARTER TR 1991 The potential effects of climatic change on agricultural insect pests. Agr Forest Meteorol 57 (1-3): 221-240. DOI: https://doi. org/10.1016/0168-1923(91)90088-8

51. BENTZ BJ, LOGAN JA, AMMAN GD 1991 Temperaturedependent development of the mountain pine beetle (Coleoptera, Scolytidae) and simulation of its phenology. Can Entomol 123 (5): 1083-1094. DOI: https://doi. org/10.4039/Ent1231083-5
52. NETHERER S, MATTHEWS B, KATZENSTEINER K, BLACKWELL E, HENSCHKE P, HIETZ P, PENNERSTORFER J, ROSNER S, et al. 2014 Do water-limiting conditions predispose Norway spruce to bark beetle attack? New Phytol 205 (3): 11281141. DOI: https://doi.org/10.1111/nph.13166

53. ALLEN CD, MACALADY AK, CHENCHOUNI H, BACHELET D, MCDOWELL N, VENNETIER M, KITZBERGER T, RIGLING A, et al. $2010 \mathrm{Global}$ overview of drought and heat induced tree mortality reveals emerging climate change risk for forests. Forest Ecol Manag 259 (4): 660-684. DOI: https:// doi.org/10.1016/j.foreco.2009.09.001

54. BENTZ BJ, RÉGNIÈRE J, FETTIG CJ, HANSEN EM, HAYES JL, HICKE JA, KELSEY RG, NEGRÓN JF, et al. 2010 Climate change and bark beetles of the western United States and Canada: direct and indirect effects. Bioscience 60 (8): 602 613. DOI: https://doi.org/10.1525/bio.2010.60.8.6

55. KRAMS I, DAUKŠTE J, KIVLENIECE I, BRŪMELIS G, CIBULLSKIS $R, \bar{A} B O L I N S S$-ĀBOLS M, RANTALA MJ, MIERAUSKAS P, et al. 2012 Drought-induced positive feedback in xylophagous insects: Easier invasion of Scots pine leading to greater investment in immunity of emerging individuals. Forest Ecol Manag 270: 147-152. DOI: https://doi.org/10.1016/i. foreco.2012.01.012

56. RAFFA KF, BERRYMAN AA 1983 The role of host plant resistance in the colonization behavior and ecology of bark beetles (Coleoptera: Scolytidae). Ecol Monogr 53 (1):2749. DOI: https://doi.org/10.2307/1942586

57. LIEUTIER F 2004 Host resistance to bark beetles and its variations. In: Lieutier F, Day R, Battisti A, Grégoire JC, Evans $\mathrm{HF}$ (eds) Bark and wood boring insects in living trees in Europe, a synthesis. Springer, Dordrecht, The Netherlands, pp 135-180

58. GRÉGOIRE JC, EVANS HF 2004 Damage and control of BAWBILT organisms, an overview. In: Lieutier F, Day R, Battisti A, Grégoire JC, Evans HF (eds) Bark and wood boring insects in living trees in Europe, a synthesis. Springer, Dordrecht, The Netherlands, pp 19-38

59. LEE S, KIM JJ, BREUIL C 2006 Pathogenicity of Leptographium longiclavatum associated with Dendroctonus ponderosae to Pinus contorta. Can J Forest Res 36 (11): 2864-2872. DOI: https://doi.org/10.1139/x06-194

60. KLEPZIG KD, ADAMS AS, HANDELSMAN J, RAFFA KF 2009 Symbioses: a key driver of insect physiological processes, ecological interactions, evolutionary diversification and impacts on humans. Environ Entomol 38 (1): 67-77. DOI: https://doi.org/10.1603/022.038.0109

61. HORN A, KERDELHUÉ C, LIEUTIER F, ROSSI JP 2012 Predicting the distribution of the two bark beetles Tomicus piniperda and $T$. destruens in Europe and the Mediterranean region. Agr Forest Entomol 14 (4): 358-366. DOI: https://doi. org/10.1111/j.1461-9563.2012.00576.x 